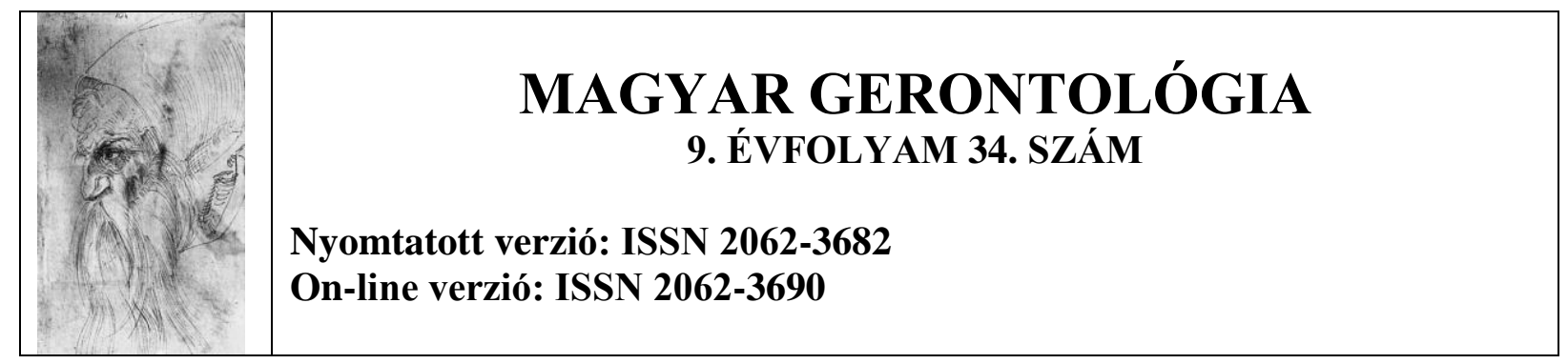

\title{
Okostelefon-használat időseknél
}

Kassai Anett-dr. Pék Gyözö PhD

Kulcsszavak: időskori okostelefon használat, okostelefon addikció, problémás okostelefon használat

\section{Összefoglalás}

Az okostelefon használat életünk nélkülözhetetlen részévé vált. Az okostelefonok folyamatos internetelérhetőség, a letölthető alkalmazások óriási száma minden korosztály számára lehetőséget nyújtanak a kapcsolattartásra, a szórakozásra és az ügyintézésre. Publikációnkban áttekintjük az időskori okostelefon használattal kapcsolatos kutatási eredményeket. A problémás használat bemutatását követően, az idős és fiatal felhasználók közötti különbségek bemutatására fókuszálunk. A problémás használat a fiatalabb korosztályokban jellemző. A készülékhasználat motivációja, a használt alkalmazások jelentősen különböznek a fiatalabb és idősebb korosztályok között. Az eredmények szerint, az idősek gyakran motiváltak az okostelefon használatára, az excesszív használatot feltételezhetően a korral együtt járó testi problémák, a pénzügyi nehézségek, valamint a készülékkel kapcsolatos ismeretek hiánya gátolja.

\section{Summary}

\section{Smartphone usage among elderly}

Smartphone usage is a necessary part of out life. The permanent internet access provided by smartphones, and the huge number of downloadable applications give opportunity to keeping contact, entertain and administration for all ages. In our publication we review the results of researches regarding smartphone usage among elderly. After introduce the problematic smartphone use we focus on the differences of young and older users. Problematic usage is a characteristic of youth users. There is a significant differences among young and older users in the field of the motivation basis of smartphone usage, and the used applications. According to the results seniors are often motivated to smartphone use but excessive usage is inhibited by physical problems, financial difficulties and the lack of knowledge relation to gadgets. 


\section{Az okostelefon addikció}

Az okostelefon addikció a szerencsejáték zavarhoz hasonlóan, a viselkedési addikciók közé sorolható, amelyek a kémiai addikcióknál megfigyelhető jellegzetességeket mutatják (Körmendi, 2011; Körmendi és Kuritárné, 2007). Az okostelefon addikció ugyanakkor nem jelenik meg a diagnosztikus kézikönyvekben más, új keletủ viselkedési addikcióhoz (például internet addikcióhoz) hasonlóan. Az addikció, vagy a problémás használat jelenlétét a következő tünetekből azonosíthatjuk (Katona és Körmendi, 2012; Körmendi és mtsai, 2014, Körmendi, 2015):

- a napi készülékhasználati idő növekedése (tolerancia)

- a személy szorong, zavart, agresszív, ha elveszíti, otthon hagyja a készülékét, esetleg akadályozzák használatában (elvonási tünetek)

- a személy a készüléket érzelmi állapotainak befolyásolására használja (coping)

- excesszív használat, kontrollvesztés, absztinenciát követő visszaesések

- a készülékhasználat következtében az élet különböző területein problémák alakulnak ki

- sóvárgás, a kognitív folyamatok a készülékre irányulnak, a viselkedés a készülékhasználat biztosítására irányul

Ugyanakkor különböző szerzők elképzelései eltértek a probléma definiálásának tekintetében.

A problémás okostelefon-használat prevalenciája 3,1\%-tól 64\%-ig terjed, a gyakoriság korcsoportonként különbözik, és egyéb demográfiai jellemzők is jelentősen befolyásolják (Gutierrez, Fonseca és Rubio, 2016). A problémás használattal és okostelefon addikcióval kapcsolatos prevalencia vizsgálatok a serdülő és a fiatal felnőttkorra fókuszálnak, továbbá az időskori használatról nagyon kevés információt találhatunk. Általánosságban, a prevalencia alacsonyabb az idősebb korosztályokat tartalmazó mintákban. Például, Lu és munkatársai a 22-59 évesek között, az addikció 3,1\%-os prevalenciáját mutatta ki 2011-ben.

\section{Időskori okostelefon használat}

Az időskori problémás okostelefon használattal kapcsolatosan kevés vizsgálati eredményt találhatunk. Magyarországon a témában még nem jelent meg tanulmány. A idősebb korosztályokban mért alacsonyabb prevalencia értéket feltehetőleg az idősek okostelefon használattal kapcsolatos nehézségei eredményezik.

Az időskorral együtt járó testi problémák jelentősen akadályozzák az okostelefonhasználatot. Az érintőképernyős irányítás finommotoros koordinációt kíván. A kijelzőkön és 
nyomtatott felhasználói kézikönyvekben található, apró betűk nagyon nehezen olvashatóak az idősebb személyek számára (Leung és mtsai, 2012; Massimi és mtsai, 2007).

Az új készülékek megismerési módjai is különbözőek korcsoportonként. Leung és mtsai (2012) alapján, a fiatalok szeretik felfedezni és kipróbálni az új készülék funkcióit és alkalmazásait, gyakran nem használnak leírásokat és segédleteket. Az idősek ezzel ellentétben, inkább a nyomtatott leírásokra hagyatkoznak, és nem próba-szerencse viselkedéssel fedezik fel a készülékek által nyújtott lehetőségeket. Feltételezhetjük tehát, hogy az idősek számára a telefonhasználat megtanulása frusztrációt eredményezhet, és segítséget igényelnek a folyamat során. Az okotelefon használat során megjelenő frusztrációt jelzik az idősek készülék irányításával kapcsolatos preferenciái. Kurniawan és munkatársai (2006), valamint Nasir és munkatársai (2008) eredményei szerint, az idősebb felhasználók a lenyomáskor hangot kiadó fémgombokat kedvelik a hang nélkül müködő gumigombokkal szemben, mivel a hangot kiadó gombok segítségével könnyebben és megbízhatóbban irányítják készüléküket. Több kutatás alapján elmondhatjuk, hogy az idősebb személyek az okostelefonokkal szemben az érintőképernyőt nem használó, gombokkal és egyszerübb funkciókkal rendelkező készülékeket használják (Culen és Bratteteig, 2013).

Kurniawan és mtsai (2006) alapján, az idősebb korosztály okostelefon-használatával kapcsolatos motivációi a biztonság témaköre köré csoportosulnak. A telefont vészhelyzet esetében fontos eszköznek tartják, ez a mozgásukban korlátozott személyek esetében inkább jellemző lehet. A családtagok elérhetőségének biztosítása szintén kiemelkedő motiváció az idősek számára, amelyet családtagjaik is támogatnak. Pee és mtsai (2014) azt találták, hogy az idősek gyakran családtagjaik biztatására, míg a fiatalok saját akaratukból vásárolnak készüléket. Ezzel szemben, a fiatalabb korcsoportok számára a készülékek kapcsolattartó, valamint szórakoztató funkciói fontosabbak (Körmendi, 2015).

A preferált készülékfunkciók tehát különbözőek a fiatal és idős felhasználóknál. Choi és munkatársai (2015) fiatal felhasználókat vizsgálva kimutatták, hogy a lányok a kapcsolattartó, míg a fiúk inkább a szórakoztató funkciókat preferálják. Bhutta, Sheikh és Yousaf (2017) az idősek által leggyakrabban használt készülékfunkciókat tanulmányozták. A leggyakrabban használt funkciók sorrendben a következőek: telefonhívások, idő és dátumjelző, vészhelyzeti jelzés, címtár, kamera, számológép, ébresztő, internet, naptár, zseblámpa. A felhasználói profilból tehát szinte teljesen hiányoznak a szórakoztató funkciók, és a szöveges kapcsolattartó funkciók, például az SMS, vagy az e-mail. Úgy tünik, hogy az idősek a készülékek praktikus, mindennapi életet megkönnyítő funkcióit használták 
elsődlegesen. Erre az igényre reagálva jelentős számú kutatást találhatunk, amelyek az idősek életminőségét javító és segítő készülékfunkciókkal foglalkoznak (Del Rosario és mtsai, 2014). Az okostelefon megítélését tekintve is jelentős különbségeket találhatunk. A fiatal felhasználók a készüléket szükséges eszközként értékelik, míg az idősek inkább luxuscikként értelmezik (Smith, 2013; Pee és mtsai, 2014).

Mohadisdudis és Ali (2014) időskorú, 60 év feletti felhasználóval készítettek telefonhasználattal kapcsolatos szokásokra és attitüdökre fókuszáló interjút. Az eredmények szerint, az idősek a készülék szórakoztató funkcióit alig használják. A leggyakrabban használt funkciók a kapcsolattartás köré szerveződnek. A telefonhívások használata a legjellemzőbb, és szöveges üzeneteket is olvasnak. Az üzenetírás azonban kevésbé jelenik meg, mivel az üzenetírással kapcsolatos nehézségek akadályozzák a használatot. A látásromlás következtében az idősek számára problémát okoz az üzenetek elolvasása, a finommotoros koordináció nehézségei pedig az üzenetírást akadályozták. Az üzeneteket több, gyakran nem megfelelő számra küldték el, és a küldött szöveget is félregépelték. Ezért a vizsgált minta tagjai elsősorban a szóbeli kommunikációt részesítették előnyben telefonhívások formájában. A minta tagjai kifejezték érdeklődésüket az okostelefonok iránt, azonban számos tényező akadályozta a használatot, amelyek az interjúk során ismétlődően megjelentek:

- A multifunkciós okostelefonok ára jelentősen magasabb, mint a kevesebb funkcióval rendelkező nyomógombos készülékek ára. Az idősek számára az okostelefon vásárlása gyakran pénzügyi problémák miatt nem megoldható.

- Az okostelefonon található operációs rendszer müködésének megértése nehézségeket okozott az idősek számára.

- Vizuális és motoros funkciók romlása következtében az okostelefonokon elérhető funkciók és alkalmazások egy részét az idős személyek nem, vagy kevésbé tudták használni.

Vorrink és munkatársai idős személyek új technológiákhoz való viszonyát tanulmányozva hasonló eredményeket közöltek (2016). Eredményeik szerint, az idősebb (65 év feletti) személyek az új technológiai eszközök használatában nehézségeket éltek át, melyek a fiatalabb korcsoportnál nem jelentek meg.

\section{Összefoglalás}

A kutatási eredmények alapján, az idősebb korcsoport kevésbé veszélyeztetett a problémás okostelefon-használat és az okostelefon addikció kialakulása szempontjából. Alacsonyabb 
prevalencia értéket mutatnak, amely az okostelefon használattal kapcsolatos nehézségeikből ered. Az okostelefonokon használt alkalmazásaik elsősorban a mindennapi élet segítésére alkalmaz programokat jelentik, illetve a szóbeli kapcsolattartást segítő funkciók is használatosak. A felhasználói profil nem, vagy kevésbé tartalmaz olyan addikcióhoz kapcsolható tevékenységeket, mint például a közösségi oldalak használata, vagy az online játékok használata. Az okostelefon birtoklás motiváció szintén a biztonsággal és a kapcsolattartással kapcsolatosak. Az addikció kialakulásához leginkább köthető szórakoztató funkciók használata kevésbé jellemző időseknél. A felhasználással kapcsolatos nehézségeik feltételezhetően preventív jellegűek a problémás használat és az addikció kialakulása szempontjából.

\section{Irodalomjegyzék}

Bhutta Z. I, Sheikh J. A, Yousaf A. (2017, July): Usage of Mobile Phones Amongst Elderly People in Pakistan. In International Conference on Applied Human Factors and Ergonomics (pp. 621-630). Springer, Cham.

Choi S. W, Kim D. J, Choi J. S, Ahn H, Choi E. J, Song W. Y, Seohee K, Youn H. (2015): Comparison of risk and protective factors associated with smartphone addiction and Internet addiction. Journal of Behavioral Addictions 4 (4): 308-314.

Culén A. L, Bratteteig T. (2013): Touch-screens and elderly users: A perfect match?. Changes 7: 15.

Del Rosario M. B, Wang K, Wang J, Liu Y, Brodie M, Delbaere K, Lovell N. H, Lord S. R, Redmond S. J. (2014): A comparison of activity classification in younger and older cohorts using a smartphone. Physiological measurement 35 (11): 2269.

Gutiérrez J. D. S, de Fonseca F. R, Rubio G. (2016): Cell-phone addiction: a review. Frontiers in Psychiatry 7.

Körmendi A. (2011): A kóros játékszenvedély kognitív megközelítése. Debreceni Egyetemi Kiadó, Debrecen.

Körmendi A, Kuritárné Sz. I. (2007): Kóros játékszenvedély: összefoglaló tanulmány az aktuális kutatásokról. Psychiatria Hungarica 22 (5): 344-365.

Katona Zs, Körmendi A. (2012): Maladaptív sémák vizsgálata szerencsejátékosok között. Psychiatria Hungarica 27 (6): 435-445.

Körmendi A, Brutóczki Z, Végh B. P, Székely R. (2014): Smartphone use can be addictive?A case report. Journal of Behavioral Addictions 5 (3): 548-552.

Körmendi A. (2015): Serdülők okostelefon-használata. Psychiatria Hungarica 3: 16-20. 
Kurniawan S, Mahmud M, Nugroho Y. (2006, April). A study of the use of mobile phones by older persons. In CHI'O6 extended abstracts on Human factors in computing systems (pp. 989-994). ACM.

Lu X, Watanabe J, Liu Q, Uji M, Shono M, Kitamura T. (2011): Internet and mobile phone text-messaging dependency: Factor structure and correlation with dysphoric mood among Japanese adults. Computers in Human Behavior 27 (5): 1702-1709.

Leung R, Tang C, Haddad S, Mcgrenere J, Graf P, Ingriany V. (2012): How older adults learn to use mobile devices: Survey and field investigations. ACM Transactions on Accessible Computing (TACCESS) 4 (3): 11.

Massimi M, Baecker R. M, Wu M. (2007, October). Using participatory activities with seniors to critique, build, and evaluate mobile phones. In Proceedings of the 9th international ACM SIGACCESS conference on Computers and accessibility (pp. 155-162). ACM.

Mohadisdudis H. M, Ali N. M. (2014, September): A study of smartphone usage and barriers among the elderly. In User Science and Engineering (i-USEr), 2014 3rd International Conference on (pp. 109-114). IEEE.

Nasir M. H. N. M, Hassan H, Jomhari N. (2008): The use of mobile phones by elderly: A study in Malaysia perspectives. Journal of Social Sciences, 4 (2): 123-127.

Pee N. C, Maksom Z, Norizan A. R. (2014): Factor influencing the use of smart phone by Malaysian's elderly. Journal of theoretical and applied information technology 59 (2): 421425.

Smith. (2013, June 5). Smartphone Ownership 2013 [Online]. Available: http://www.pewinternet.org/2013/06/05/smartphoneownership-2013/

Vorrink S. N, Antonietti A. M, Kort H. S, Troosters T, Zanen P, Lammer J. W. J. (2016): Technology use by older adults in the Netherlands and its associations with demographics and health outcomes. Assistive Technology 1-8.

\section{Szerzők:}

Kassai Anett PhD hallgató

DE BTK Pszichológiai Intézet

Személyiség-és Klinikai Pszichológiai Tanszék

e-mail: kassaianett@gmail.com

dr. Pék Győző PhD egyetemi docens

DE BTK Pszichológiai Intézet

Személyiség-és Klinikai Pszichológiai Tanszék

e-mail: viktorbaker55@gmail.com 